\title{
Rheumatoid arthritis and gut related lymphocytes: the iteropathy concept
}

\author{
P SHELDON \\ From the Department of Microbiology, Medical Sciences Building, Leicester
}

The aetiology of rheumatoid arthritis (RA) remains unknown. The involvement of the gut in reactive arthritis $(\operatorname{Re} A)$ and of the genitourinary system in Reiter's syndrome (RS), though recognised, is poorly understood. Distribution of phlogistic products via Batson's plexus has been suggested to account for the distribution of involved joints in these conditions. ${ }^{1}$ Ankylosing spondylitis (AS) too has been associated with gut bacteria, including Klebsiella pneumoniae. ${ }^{2}{ }^{3}$ It is possible that sulphasalazine, for which efficacy has been claimed in all these conditions, ${ }^{4-6}$ may mediate its effects by immunosuppression of the gut associated lymphoid tissue (GALT). This is because only at concentrations above those found in the blood stream is it immunosuppressive in vitro. ${ }^{78}$ If this also applies in vivo it opens up a whole new vista of possibilities regarding the aetiopathogenesis of these disorders.

The gut is a lymphoid organ at the heart of the secretory immune system, which is known to be involved in immune protection at mucosal surfaces and is largely mediated by IgA. It also includes certain other sites, however, which, though not strictly mucosal, have functions that are anatomically and functionally close. These include the salivary, lacrimal, and mammary glands. There is a reasonable body of evidence to indicate that these sites are normally colonised by lymphocytes or plasma cells, or both, that have seeded there from GALT, ${ }^{9-13}$ which is regarded as the major component of the mucosa associated lymphoid tissue. Mucosa associated lymphoid tissue comprises certain other sites, including the bronchi associated lymphoid tissue and the genitourinary tract lymphoid tissue. Homing tendencies of lymphocytes appear to be determined by adhesins, ${ }^{14}$ detectable using monoclonal anti-

Accepted for publication 27 March 1988.

Correspondence to Dr P Sheldon. Department of Microbiology. PO Box 138. Medical Sciences Building. University Road. Leicester LEI OHN. bodies, the cells emerging within the lymphoid tissues at sites termed high endothelial venules. ${ }^{15} 10$ It has, on good authority, been stated that high endothelial venules are not present in mucosal tissues outside of GALT. ${ }^{17}$ Yet they have also been demonstrated in synovial membrane. ${ }^{18}$ In addition. $\operatorname{IgA}$ rheumatoid factor has been demonstrated in synovial membrane plasma cells, though the predominant class of antibody is $\operatorname{IgG}{ }^{19}$ It has also been demonstrated in synovial fluid, particularly high levels having been found in Sjögren`s syndrome. ${ }^{20}$ and in saliva of patients with RA and with Sjögren's syndrome. ${ }^{21}$ The serum and salivary IgM rheumatoid factor activities were more closely correlated than were the corresponding $\operatorname{Ig} \mathrm{A}$ rheumatoid factor levels, suggesting local production in salivary gland. The predominance of the polymeric as distinct from the monomeric form of $\operatorname{IgA}$ rheumatoid factor, whether as found in synovial fluid ${ }^{20}$ or in synovial cell supernatants in vitro, ${ }^{10}$ bears testimony to the likely mucosal origin of the producing cells.

These findings imply the existence of a link between GALT and synovial membrane. Thus it may be suggested that gut lymphocytes, which have been shown to home physiologically to lacrimal or salivary glands, or both, in health, may, for reasons as yet not understood, do so pathologically giving rise to the sicca syndrome. Should they emerge solely in synovial membrane, RA might ensue, as a consequence perhaps of response to a cross reacting antigen. This may have been initially encountered in the intestinal lumen or wall, e.g., a component of bacterial cell wall that possesses epitope similarity with articular cartilage. ${ }^{22}$ Should they emerge at both sites, Sjögren's syndrome would be the result.

Another intriguing and well recognised fact in RA is the amelioration of the disease in many women during and for several months after pregnancy. During this time it has been shown that lymphocytes home to mammary gland and produce $\lg A$ that is 
protective to the newborn infant. This homing is hormone dependent. ${ }^{23}$ Immunohistological studies of lactating human mammary glands have shown densities of $\operatorname{IgA}$ producing cells of $65-70 / \mathrm{mm}^{2}$ compared with approximately $60 / \mathrm{mm}^{2}$ for normal parotid glands, $120 / \mathrm{mm}^{2}$ for submandibular glands, $460 / \mathrm{mm}^{2}$ for lacrimal glands, and $516 / \mathrm{mm}^{2}$ for colonic mucosa. Far fewer produced $\mathrm{IgG}^{24}$ The overall number of plasma cells is far higher in the lactating than the resting breast. ${ }^{25}$ Thus it seems reasonable to suggest that some of the $\mathrm{IgG}$ and much of the $\operatorname{IgA}$ synthesis that is known to take place in active rheumatoid synovial membrane may also take place (physiologically) in mammary gland. In other words the breast tissues of a pregnant patient with RA may compete with other mucosa associated lymphoid tissue, the net effect being the diversion of some of the cells that would otherwise home to the joints. A similar though less well characterised phenomenon may occur in placenta, where lymphocytes have been detected between decidual cells. With the aid of a recently described monoclonal antibody, HML-1, which recognises a novel membrane molecule present on intestinal intraepithelial lymphocytes, it has been shown that breast lymphocytes and one third to one fifth of these placental lymphocytes are positive. ${ }^{26}$ Thus one may imagine the breast and placenta selectively depleting lymphocytes that would otherwise participate in the rheumatoid process within joints, a technique that bears a certain similarity to the depletion achieved by thoracic duct cannulation and drainage. It will be remembered that a large proportion of thoracic duct lymphocytes will have come from GALT en route to the mesenteric vasculature. Thoracic duct cannulation and drainage have been applied with some benefit in the management of intractable $\mathrm{RA}^{27}$ Interestingly, infusion of live thoracic duct lymphocytes from a patient with RA into her joints produced inflammation, but not when killed thoracic duct cells were employed. ${ }^{27}$

One may naturally feel keen to try out HML-1 on lymphoid infiltrates seen in chronically inflamed synovial membranes, be they from RA, ReA, RS, or AS. The answer would be intriguing whatever the result. Should these cells be positive, this would be strong evidence of their origin from intestinal epithelium or lamina propria. Should they be negative, this could be interpreted as evidence of their origin from pre-intraepithelial lymphocytes or pre-lamina propria lymphocytes, i.e., they could have originated from Peyer's patches, which possess few HML-1 positive cells, or from mesenteric nodes. Their itinerary would have taken them through the thoracic duct, the blood stream, and then via high endothelial venules to synovial membrane, instead

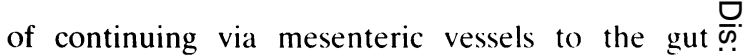
epithelium or lamina propria.

A difficulty arises through the fact that most $\stackrel{\bar{m}}{+}$ lymphocytes in the synovial infiltrates in rheumatoid arthritis have been shown to consist of CD3+, 을 $\mathrm{CD} 4+$ cells, ${ }^{28}$ whereas most intraepithelial lympho- $\frac{\text { क }}{\sigma}$ cytes are CD3+, CD8+. ${ }^{26}$ This does not apply to all $\stackrel{\odot}{\circ}$ GALT, however. Indeed the Peyer's patches and $\%$ mesenteric lymph node cells are predominantly $\overrightarrow{0}$ $\mathrm{CD} 3+, \mathrm{CD} 4+.{ }^{17}$ Another question is that of HLA-DR expression. This is prominent in the $\vec{\omega}$ rheumatoid synovium ${ }^{29}$ and nodule. ${ }^{31}$ HLA-DR is also expressed on normal intestinal villous epi- $\frac{0}{2}$ thelium. ${ }^{31}$ Enhanced expression has been found in coeliac disease and dermatitis herpetiformis, ${ }^{32}$ io ulcerative colitis, and Crohn's disease. ${ }^{33}$ The dis- 8 crepancy in degree of expression of HLA-DR in normal intestine and rheumatoid synovium cannot as yet be explained. Studies of HLA-DR expression in rheumatoid intestine might prove interesting, however, as the rheumatoid gut may not be as normal as has been assumed. ${ }^{34}$

If we include the synovial membrane as part of the $\vec{\bullet}$ secretory immune system then the pattern of $\infty_{\infty}^{\infty}$ involvement of seemingly unrelated tissues within 0 this system falls into place. It is difficult otherwise to imagine how an antigen itself would specifically seek out these sites, but easier to construe that some primary fault in the migratory behaviour of lympho- $\frac{D}{\mathbb{D}}$ cytes operating within the secretory immune system could result in pathological sequelae at various points within the system. Such an abnormality may be viewed as an 'iteropathy' (iter-journey). Further studies into extrinsic and genetic factors affecting the itinerant proclivities of gut related $\frac{0}{2}$ lymphocytes may yield useful information regarding $\frac{2}{\sigma}$ the aetiopathogenesis of rheumatoid arthritis and 3 Sjögren's syndrome as well as the seronegative arthritides.

Dumonde has stated 'It is our view that lymphocyte activation products such as the lymphokine factors regulate the balance between inflammatory을. surveillance and adjuvant function of the cellular immune response by acting on cell co-operation or $\Omega$ by controlling the traffic of lymphoid cell popula- $N$ tions through critical regions of lymphoid and $\underset{\omega}{N}$ vascular tissue, ${ }^{35}$

The above arguments are in agreement with these remarks, except that the role attributed by Dumonde to lymphokines may in iteropathies be ascribed $\stackrel{9}{\rightarrow}$ to exogenous agents. The iteropathy concept is intended to provoke thought about intestinal $\overrightarrow{0}$ lymphocyte itineraries and the circumstances that $\overrightarrow{\mathbb{Q}}$ may disturb them. These may include diet. As an example, vitamin A deficiency or protein-calorie $\varrho$ malnutrition in rats have been shown to impair 
localisation of mesenteric lymphoblasts following adoptive transfer ${ }^{36}$ Another candidate would be gut infection as seen in ReA. In either case the pathological process would be deemed to commence as a result of an iteropathy, the subsequent pathological events being dependent upon the initiating cause. In one scenario the antigen would gain entry to the joint as a passenger bound to a lymphocyte that it had rendered iteropathic, e.g., chlamydia (J Dixey et al, unpublished data) or parvovirus. ${ }^{37} \mathrm{In}$ another scenario the iteropathy could be induced within the GALT by an extrinsic antigen, e.g., bacterial cell wall, and the subsequent events within the joints could possibly be the result of cross reactivity.

Yet another version that has a certain appeal concerns the interaction of microbial products and HLA antigens. In AS the HLA-B27 antigen has been shown to possess receptor properties for the 'modifying factor' released by certain plasmid infected enteric bacteria. ${ }^{38}$ Might this modifying factor also modify the subsequent itinerant properties of HLA-B27+ GALT cells? If this were so it would raise similar questions for other arthropathies once the principle was established.

All these scenarios assume the lymphocyte itself to be iteropathic. An alternative possibility is that the iteropathy is the result of qualitative changes in high endothelial venules induced by these antigens. In this context it is of interest to note that several agents, including bacterial lipopolysaccharide, stimulate lymphocyte-endothelial cell adhesion in tissue culture. ${ }^{39}$ This, however, leaves unexplained how they reach the high endothelial venules and why they should affect such seemingly unrelated sites. Thus when the routes taken physiologically by GALT are known it requires less imagination to conclude that these lymphocytes should be the target of disease causing agents, rather than the end organs (i.e., the joints) characteristic of the ensuing disease.

Whatever the mechanism(s), the subject of lymphocyte traffic is at last receiving increasing attention. ${ }^{40}+1$ It is to be hoped that if this should indeed prove to be the fundamental link between gut and joint pathology in these diseases more effective treatment will be forthcoming, particularly for RA. This will require us to focus our therapeutic endeavours on the iteropathy rather than the consequences of chronic inflammation.

\section{References}

1 Ziff M. Heberden oration 1964. Some immunologic aspects of the connective tissue discases. Ann Rheum Dis 1965: 24: 103-15.

2 Ebringer A, Cowling P. Ngwa-Suh N, James D C O, Ebringer R W. Cross-reactivity between Klebsiclla aerogenes species and
B-27 lymphocyte antigens as an aetiological factor in ankylosing spondylitis. In: Dausset J. Svejgaard A. eds. HLA and disease. Paris: INSERM. 1976: 58: 27.

3 Seager K. Bashir H V. Geczy A F. Edmonds J. De Vere Tyndall A. Evidence for a specific B-27 associated cell surface marker on lymphocytes of patients with ankylosing spondylitis. Nature 1979; 277: 68-70.

4 Pullar T. Hunter J A. Capell H A. Sulphasalazine in the treatment of rheumatoid arthritis: relationship of dose and scrum levels to efficacy. Br J Rheumatol 1985: 24: 269-76.

5 Miclants H. Veys E M. Joos R. Sulphasalazine (Salazopyrin) in the treatment of enterogenic reactive synovitis and ankylosing spondylitis with peripheral arthritis. Clin Rheumatol 1986: 5: $80-3$.

6 Dougados M. Boumier P. Amor B. Sulphasalazine in ankylosing spondylitis: a double blind controlled study in 60 patients. $\mathrm{Br}$ Med J 1986; 293: 911-4.

7 Sheldon P. Webb C. Grindulis K. Sulphasalazine in rheumatoid arthritis: pointers to a gut-mediated immune effect. $\mathrm{Br} J$ Rheumatol 1987: 26: 1-4.

8 Ali A T. Basran G S. Morley J. Mode of action of sulphalazine: an alternative view. Lancel 1982; i: 5(6-7.

9 Montgomery P C. Ayvildiz A. Lemaitre-Coclho I S. Vacrman $\mathrm{J}-\mathrm{P}$. Rockey $\mathrm{J} \mathrm{H}$. Induction and expression of antibodies in secretions: the ocular immune system. Ann NY Acad Sci 1983: 409: $428-40$.

10) Jackson D. Lally M. Nakamura M. Montgomery P C. Migration of IgA bearing lymphocytes into salivary glands. Cell Immunol 1981: 63: 203-9.

11 McDermott M. Bienenstock J. Evidence for a common mucosal immunologic system. 1. Migration of B lymphoblasts into intestinal. respiratory and genital tissues. J Immunol 1979: 122: 1892-7.

12 Allardyce R A. Shearman D J C. McClelland D B L. Marwick K. Simpson A J. Laidlaw R B. Appearance of specific colostrum antibodies after clinical infection with Salmonella typhimurium. Br Med J 1974; ii: 307-9.

13 Goldblum R M. Ahlstedt S. Carlsson B. et al. Antibody forming cells in human colostrum after oral immunisation. Nature 1975: 257: 797-9.

14 Gallatin W. Weissman I. Butcher E. A cell-surface molecule involved in organ-specific homing of lymphocytes. Nature 1983: 304: 30-4.

15 Pals S. Kraal G. Horst E. de Groot A. Scheper R J. Meijer C J L M. Human lymphocyte high endothelial venule interaction: organ-specific binding of $T$ and $B$ lymphocyte populations to high endothelium. J Immunol 1986: 137: 76(2-3.

16 Jalkanen $\mathrm{S}$. Butcher $\mathrm{E}$. In vitro analysis of the homing properties of human lymphocytes: developmental regulation of functional receptors for high endothelial venules. Blood 1985; 66: $577-82$.

17 Parrott D M V. The structure and organization of lymphoid tissue in the gut. In: Brostoff $\mathrm{J}$. Challacombe $\mathrm{S} J$, eds. Food allergy and intolerance. London: Ballière Tindall. 1987: 3-26.

18 Freemont A J. Molecules controlling lymphocyte-endothelial interactions in lymph nodes are produced in vessels of inflamed synovium. Ann Rheum Dis 1987: 46: 924-8.

19 Koppman W J. Miller R K. Crago S S. Mestecky J. Schrohenloher R E. IgA rheumatoid factor: evidence for independent expression at local sites of tissue inflammation. Ann NY Acad Sci 1983; 409: 258-72.

20 Elkon K B. Delacroix D L. Gharavi A E. Vacrman J P. Hughes $G R V$. Immunoglobulin $A$ and polymeric $\operatorname{Ig} A$ rheumatoid factors in systemic sicca syndrome: partial characterization. J Immunol 1982; 129: 576-81.

21 Dunne J V. Carson D A. Spiegelberg H L. Alspaugh M A, Vaughan $\mathrm{J} \mathrm{H}$. IgA rheumatoid factor in the sera and saliva of patients with rheumatoid arthritis and Sjögren's syndrome. Ann Rheum Dis 1979: 38: 161-5.

22 Holoshitz J, Drucker I, Yaretzky A. et al. T lvmphocytes of 
rheumatoid arthritis patients show augmented reactivity to a fraction of mycobacteria cross-reacting with cartilage. Lancet 1986: ii: $305-9$.

23 Wcisz-Carrington P. Roux M E. McWilliams M. PhillipsQuagliata J M. Lamm M E. Hormonal induction of the secretory immune system in the mammary gland. Proc Natl Acad Sci USA 1978: 75: 2928-32.

24 Brandtzaeg $P$. The secretory immune system of lactating human mammary glands compared to other exocrine organs. Ann NY Acad Sci 1983; 409: 353-82.

25 Pumphrey R J H. A comparative study of plasma cells in the mammary gland in pregnancy and lactation. Symposia of the Zoological Society, London 1977; 41: 261-76.

26 Cerf-Bensussan N. Jarry A. Brousse N. Lisowska-Grospierre B. Guy-Grand D. Griscelli C. The demonstration of antigen detectable by monoclonal antibody HML- 1 on the membranes of a high percentage of infiltrating lymphocytes. Eur J Immunol 1987: 17: 1279-85.

27 Paulus H. Machleder H. Levine S. Yu D T Y. MacDonald N S. Lymphocyte involvement in rheumatoid arthritis. Studies during thoracic duct drainage. Arthritis Rheum 1977: 20: 1249-62.

28 Kurosaka M, Ziff M. Immunoclectron microscopic study of the distribution of $\mathrm{T}$ cell subsets in rhcumatoid synovium. Exp $J$ Med 1983: 158: 1191-210.

29 Klareskog L. Forsum U. Wigren A. Wigzell H. Relationship between HLA-DR expressing cells and $T$ lymphocytes of different subsets in rheumatoid synovial tissuc. Scand J Immunol 1981: 15: 501-7.

30) Duke O L. Hobbs S. Panavi G S. Poulter L W. Rasker J J. Janossy G. A combined immunohistological and histochemical analysis of lymphocytes and macrophage subpopulations in the rheumatoid nodule. Clin Exp Immunol 1984: 56: 239-46.

31 Scott H. Solhcim B G. Brandtzacg P. Thorsby E. HLA-DR antigens in the epithelium of the human small intestine. Scand $\frac{.9}{9}$ Immunol 1980; 12: 77-82.

32 Scott H, Brandtzacg P. Solheim B G. Thorsby E. Relation between HLA-DR like antigens and secretory component (S $\overline{\mathscr{W}}$ in jejunal epithelium of patients with coeliac disease an $\bar{\Phi}$ dermatitis herpetiformis. Clin Exp Immunol 1981: 44: 233-8.

33 Selby W S. Janossy G. Mason D Y. Jewell D P. Expression (क्ठ HLA-DR antigens by colonic epithelium in inflammatory bow disease. Clin Exp Immunol 1983: 53: 614-8.

34 Segal A W. Isenberg D A. Hajirousou V. Tolfree S, Clark Snaith M L. Preliminary evidence for gut involvement in the pathogenesis of rheumatoid arthritis? BrJ Rheumatol 1986; $2 \dot{\dot{\dot{H}}}$ 162-6.

35 Dumonde D C. Rheumatoid arthritis as a disorder of celR mediated immunity. In: Muller W. Harwerth H G. Fehr K. ed Rheumatoid arthritis. New York: Academic Press, 1971: 447-5? (Colloquia Geigy.)

36 McDermott M R. Mark D A. Befus A D. Baliga B S. Suskind R Mbo Bienenstock J. Impaired intestinal localization of mesenterio lymphoblasts associated with vitamin A deficiency and protei caloric malnutrition. Immunology 1982; 45: 1-5.

37 Simpson R W. McGinty L. Simon L. Association of parvoviruse? with rheumatoid arthritis of humans. Science 1984; 223: $1425-8$.

38 Geczy A F, Alexander K. Bashir H V. Edmonds J. A factor in klebsiclla culture filtrates specifically modifies an HLA-B2e associated cell surface component. Nature 1980; 283: 782-4.

39 Yu C-L. Haskard D. Cavender D. Ziff M. Effects of bacteriaT lipopolysaccharide on the binding of lymphocytes to endothelia $\vec{b}$ cell monolayers. J Immunol 1986: 136: 269-73.

40) Haskard D. Lymphocyte traffic. endothelium, and rheumatoid arthritis. Ann Rheum Dis 1987; 46: 881-2.

41 Sheldon P. HLA-B27 related arthritis, sulphasalazine an rheumatoid arthritis. Br J Rheumatol 1987; 26: 321-4. 